\title{
Pengaruh Tipe Industri, Kinerja Lingkungan, Dan Profitabilitas Terhadap Carbon Emission Disclosure
}

\author{
Erika Apriliana ${ }^{1}$, Husnah Nur Laela Ermaya ${ }^{2}$, Krisno Septyan $^{3}$ \\ 1,2,3 Jurusan Akuntansi Fakultas Ekonomi dan Bisnis Universitas Pembangunan Nasional \\ Veteran Jakarta, Jl. RS Fatmawati, Pd. Labu, Cilandak, Kota Jakarta Selatan, Daerah Khusus \\ Ibukota Jakarta 12450 \\ 1erikaapriliana@gmail.com
}

\begin{abstract}
The purpose of this study was to examine the effect of Industrial Type, Environmental Performance, and Profitability on Carbon Emission Disclosure. The independent variable in this study is Industry Type which is measured using dummy variables, Environmental Performance is measured using PROPER and Profitability is measured using return on assets. Carbon Emission Disclosure as the dependent variable was measured using a checklist adopted from the research of Choi et al. The population of this study is non-financial companies registered in 2015-2017. By using purposive sampling method and obtained a total sample of 33 companies per year. The method of analysis of this study includes descriptive statistical analysis, classic assumption test, hypothesis testing and multiple linear regression. The results of this study indicate that Industry Type and Profitability have a significant effect on the level of carbon emissions disclosure. Meanwhile, Environmental Performance does not have a significant effect on the level of carbon emissions disclosure. Carbon Emission Disclosure variables can be explained by Industry Type, Environmental Performance and Profitability variables of $17.9 \%$, while the remaining $82.1 \%$ are influenced by other variables not examined in this study.

Keywords : Carbon Emission Disclosure, Voluntary Disclosures, Industrial Type, Environmental Performance, Profitability
\end{abstract}

\section{PENDAHULUAN}

Gagasan era ekonomi baru yang timbul melalui komitmen politik internasional telah disepakati secara universal di Rio de Janerio, Brazil, Juni 1992. Gagasan yang dibentuk melalui KTT Bumi (Earth Summit) tersebut bertujuan untuk mewujudkan konsep pembangunan ekonomi berkelanjutan yaitu pembangunan yang memenuhi kebutuhan generasi saat ini tanpa mengorbankan kepentingan generasigenerasi selanjutnya. United Nation Framework Convention on Climate Change (UNFCCC) menciptakan sebuah amandemen Internasional yang dikenal dengan Protokol Kyoto. Protokol Kyoto merupakan sebuah konvensi internasional yang dibuat di Kyoto, Jepang pada tahun 1997. Esensi dari konvensi tersebut ialah mewajibkan anggota Anex 1 mengurangi emisi Gas Rumah Kaca (GRK), karena perubahan iklim yang terjadi akhir-akhir ini disebabkan oleh akumulasi penggunaan energi fosil semenjak revolusi industri tahun 1850. Terdapat 6 GRK yang ditargetkan penurunannya dalam Protokol Kyoto yaitu karbon dioksida $\left(\mathrm{CO}_{2}\right)$, metana $\left(\mathrm{CH}_{4}\right)$, nitrous oksida $\left(\mathrm{N}_{2} \mathrm{O}\right)$, sulfur heksafluorida $\left(\mathrm{SF}_{6}\right)$, perfluorokarbon (PFC), dan hidrofluorokarbon (HFC) (Irwhantoko \& Basuki, 2016).

Indonesia sebagai salah satu negara yang menandatangani Protokol Kyoto, telah meratifikasi Protokol Kyoto melalui UU No. 17 Tahun 2004 dalam rangka melaksanakan pembangunan berkelanjutan serta ikut serta dalam upaya menurunkan emisi GRK global. Selain itu komitmen Indonesia dalam mengurangi emisi karbon terlihat dari adanya Perpres No. 61 Tahun 2011 mengenai Rencana Aksi Nasional Penurunan Emisi Gas Rumah Kaca dan Perpres No. 71 Tahun 2011 mengenai penyelenggaraan inventarisasi gas rumah kaca nasional. Pada pasal 4 Perpres No. 61 Tahun 2011, disebutkan bahwa pelaku usaha juga ikut andil dalam upaya penurunan emisi GRK.

Pada Tahun 2015 KTT Perubahan Iklim PBB atau COP di Paris, 
Perancis mengeluarkan Kesepakatan Paris (Paris Agreement) sebagai pengganti Protokol Kyoto untuk memerangi dampak perubahan iklim. Persetujuan ini dinegosiasikan oleh 195 perwakilan negara-negara pada Konferensi Perubahan Iklim PBB ke-21 di Paris, Prancis. Indonesia merupakan salah satu negara yang menandatangani perjanjian ini pada 22 April 2016. Persentase gas rumah kaca yang diratifikasi oleh Indonesia adalah sebesar $1,49 \%$, namun target penurunan emisi yang dicanangkan Indonesia belum cukup untuk mencapai target temperatur dibawah $2^{\circ} \mathrm{C}$. Untuk mencapai tujuan Kesepakatan Paris, para ahli mengatakan Indonesia harus memperbaiki kebijakan perlindungan hutannya, mengingat deforestasi merupakan sumber emisi tertinggi (Climate Tranparency, 2017).

Salah satu contoh penurunan kualitas lingkungan yang diakibatkan dari sektor kehutanan dan ahli fungsi lahan yaitu fenomena kebakaran gambut yang terjadi di Aceh Barat yang mencapai 69 hektare (Tribunnews, 2017). Sebagian luas wilayah Indonesia adalah hutan yang merupakan penghasil oksigen dan penyerap gas karbondioksida (paru-paru dunia). Namun, saat ini telah berubah menjadi lahan penghasil gas karbondioksida (Kementerian Lingkungan Hidup, 2012). Hilangnya cadangan karbon, membuat lahan gambut Indonesia menjadi salah satu sumber utama emisi karbon dunia. Hal ini harusnya menjadi fokus perhatian perusahaan dalam pengelolaan lahan di Indonesia jika dunia berharap untuk mengurangi emisi karbon (Pratiwi dan Sari, 2016).

Selanjutnya terdapat kasus pencemaran lingkungan oleh PT Millenium yang merupakan salah satu dari kasus pencemaran lingkungan oleh perusahaan yang ada di Indonesia. Limbah udara berupa kepulan asap hitam pekat yang dibuang perusahaan tersebut terbawa angin hingga ke rumah warga membuat kualitas udara melebihi baku mutu lingkungan yang mengakibatkan gangguan kesehatan.
Sumber dari pencemaran udara yang dikeluarkan dari empat cerobong asap PT Millenium ini dipicu oleh penggunaan bahan bakar batu bara (Okezone, 2018). Peningkatan pembakaran bahan bakar minyak, batu bara, dan bahan-bahan organik lainnya yang melampaui kemampuan tumbuhan dan laut untuk menyerapnya mengakibatkan peningkatan suhu permukaan bumi dan perubahan iklim yang sangat ekstrim di bumi (Cahya,2016)

Upaya pengurangan emisi GRK (termasuk emisi karbon) yang dilakukan oleh perusahaan sebagai pelaku usaha dapat diketahui dari pengungkapan emisi karbon (Carbon Emission Disclosure). Luas pengungkapan dapat dilakukan dengan mengacu pada kuesioner yang telah disediakan oleh Carbon Disclosure Project (CDP). CDP diselenggarakan oleh sebuah organisasi non-profit berbasis di London Inggris yang meminta perusahaan yang terpengaruh oleh pemanasan global untuk mengisi kuesioner setiap tahun (Zhang et al 2013). Fokus dari kuisioner tersebut mengenai bagaimana kondisi perusahaan dipengaruhi oleh pemanasan global atau langkah yang telah dilakukan perusahaan untuk mengurangi emisi gas rumah kaca.

Saat ini perusahaan-perusahaan di dunia secara bertahap mulai mempertimbangkan risiko yang cukup material terkait perubahan iklim, baik dampak langsung secara fisik terhadap bisnis mereka atau melalui kebijakan perubahan iklim yang mengubah pola konsumsi masyarakat (Luo et al 2013). Sudah seharusnya pelaku usaha ikut berpartisipasi menjaga kelestarian lingkungan dari dampak perubahan iklim. Salah satu cara yang dapat ditempuh adalah dengan menyertakan pengungkapan emisi karbon (carbon emission disclosure) di dalam annual report atau suistainability report perusahaan. Pada praktiknya pengungkapan emisi karbon di Indonesia masih jarang dilakukan oleh entitas bisnis karena masih merupakan voluntary disclosure. Meskipun begitu sudah semestinya perusahaan menaruh perhatian 
lebih terhadap hal ini mengingat semakin memburuknya kondisi lingkungan beberapa dasawarsa terakhir dan semakin luasnya tuntutan dari berbagai lapisan masyarakat. Perusahaan yang melakukan pengungkapan emisi karbon memiliki beberapa pertimbangan diantaranya untuk mendapatkan legitimasi dari para stakeholder, menghindari ancamanancaman terutama bagi perusahaanperusahaan yang menghasilkan gas rumah kaca (greenhouse gas) seperti peningkatan operating costs, risiko reputasi (reputational risk), pengurangan permintaan (reduced demand), proses hukum (legal proceedings), serta denda dan pinalti (Berthelot \& Robert, 2011).

\section{KAJIAN PUSTAKA}

\section{Pengaruh Tipe Industri terhadap Carbon Emission Disclosure}

Tidak semua perusahaan yang bergerak di berbagai bidang mengungkapkan aktivitasnya apabila tidak mempunyai nilai yang positif bagi perusahaan tersebut. Untuk jenis perusahaan high profile seperti pertambangan, manufaktur yang menghasilkan kerusakan lingkungan dan emisi karbon tinggi lebih parah dibandingkan dengan jenis perusahaan low profile seperti yang bergerak di bidang jasa, perdagangan, dan lain sebagainya (Jannah \& Muid, 2014). Menurut Wang et al (2013), perusahaan high profile yang aktivitas operasionalnya berdampak negatif terhadap lingkungan cenderung untuk mengungkapkan lebih banyak tanggung jawab sosial perusahaan (CSR) informasi dibandingkan low profile. Perusahaan dalam industri yang sensitif atau berdampak negatif terhadap lingkungan cenderung untuk mengungkapkan lebih lanjut CSR dari yang lain, terutama informasi CSR yang berkaitan dengan tanggung jawab lingkungan. Perusahaanperusahaan high profile yang lebih sensitif terhadap lingkungan mungkin menghadapi biaya politik yang jauh lebih tinggi daripada perusahaan low profile (Jannah \& Muid, 2014)

Uraian di atas didukung dengan hasil penelitian Jannah \& Muid (2014) yang menyatakan bahwa tipe industri berpengaruh terhadap Carbon emission disclosure. Dengan demikian, hipotesis pertama yang diajukan dalam penilitian ini adalah:

H1 : Tipe industri berpengaruh signifikan terhadap Carbon emission disclosure.

\section{Pengaruh Kinerja Lingkungan terhadap Carbon Emission Disclosure}

Menurut penelitian Dawkins dan

Fraas (2011), kinerja lingkungan mempunyai hubungan positif dengan pengungkapan lingkungan yaitu perubahan iklim. Hal ini sejalan dengan penelitian Verrechia (1983) dalam Matsumura et al (2011) yang menunjukkan bahwa perusahaan yang lebih proaktif lingkungan (misalnya, melalui inisiatif seperti pelaksanaan program pencegahan polusi yang kuat dan menggunakan energi terbarukan, dan lain-lain) memiliki insentif untuk secara sukarela mengungkapkan informasi lingkungan, seperti informasi tingkat emisi karbon dalam rangka mengungkapkan tipe kinerja mereka yang tidak secara langsung diamati oleh investor dan pemangku kepentingan eksternal lainnya. Hasil Penelitian tersebut sejalan dengan penelitian Clarkson et al (2008) menunjukkan bahwa kinerja lingkungan berasosiasi positif dengan tingkat pengungkapan lingkungan diskresioner (Jannah \& Muid, 2014). Menurut Clarkson et al (2008), perusahaan dengan kinerja lingkungan yang unggul memiliki strategi lingkungan yang proaktif. Hal tersebut mendorong perusahaan untuk menginformasikan kepada investor dan stakeholder (pemangku kepentingan) lain melalui pengungkapan sukarela mengenai lingkungan. Perusahaan berusaha untuk mengungkapkan jenis kinerja mereka melalui pengungkapan sukarela yang tidak dapat dengan mudah ditiru oleh perusahaan dengan kinerja lingkungan yang buruk. Hal 
tersebut berpotensi meningkatkan nilai perusahaan. Dengan demikian, hipotesis kedua yang diajukan dalam penilitian ini adalah:

H2: Kinerja Lingkungan berpengaruh signifikan terhadap Carbon emission disclosure.

\section{Pengaruh Profitabilitas terhadap Carbon Emission Disclosure}

Perusahaan dengan kondisi keuangan yang baik lebih mungkin untuk mengungkapkan informasi lingkungan. Kemampuan kinerja keuangan meliputi berbagai inisiatif perusahaan untuk berkontribusi dalam upaya penurunan emisi atau dalam hal ini emisi karbon seperti penggantian mesin-mesin yang lebih ramah lingkungan, ataupun tindakan lingkungan lainnya seperti aksi penanaman pohon untuk meningkatkan penyerapan $\mathrm{CO}_{2}$. Menurut Choi et al (2013), perusahaan dengan kondisi keuangan yang baik mampu membayar sumber daya tambahan manusia atau keuangan yang dibutuhkan untuk pelaporan sukarela dan pengungkapan emisi karbon yang lebih baik untuk menahan tekanan eksternal. Untuk perusahaan dengan kinerja keuangan yang buruk, pengungkapan kewajiban atau peraturan baru mengenai lingkungan di masa depan berarti biaya tambahan, yang menyebabkan kekhawatiran dari kreditor, pemasok dan pelanggan tentang kinerja perusahaan. Sebaliknya, perusahaan dengan profitabilitas tinggi mengungkapkan informasi mendapatkan sinyal bahwa mereka dapat bertindak dengan baik atas tekanan lingkungan secara efektif dan bersedia untuk menyelesaikan masalah dengan cepat. Berdasarkan uraian tersebut, maka hipotesis dalam penelitian ini adalah:

H3: Profitabilitas berpengaruh signifikan terhadap Carbon Emission Disclosure.

\section{METODOLOGI PENELITIAN}

Metode yang digunakan dalam penelitian ini adalah metode kuantitatif. Populasi yang digunakan dalam penelitian ini adalah seluruh perusahaan non keuangan yang terdaftar di BEI pada periode 2015-2017, dengan metode pengambilan sampel menggunakan Purposive Sampling dengan beberapa kriteria yang telah ditentukan yaitu, Perusahaan yang mengikuti Progam Penilaian Peringkat Kinerja Perusahaan (PROPER), menyediakan laporan tahunan atau sustainability report selama tahun 2015-2017 secara berturut-turut serta mengeluarkan kebijakan carbon emission disclosure (minimal satu kebijakan yang terkait dengan emisi karbon/gas rumah kaca atau mengungkapkan minimal satu item carbon emission disclosure). Pemilihan perusahaan non-keuangan dalam penelitian ini dikarenakan perusahaan yang menghasilkan emisi karbon lebih banyak terdapat pada industri non keuangan dan lebih banyak mempunyai dampak/pengaruh terhadap lingkungan disekitarnya akibat dari aktivitas operasional perusahaan.

Variabel-variabel yang digunakan dalam penelitian ini adalah carbon emission disclosure, tipe industri, kinerja lingkungan, dan profitabilitas. Instrumen yang digunakan untuk mengukur variabelvariabel tersebut, diadopsi dari penelitianpenelitian terdahulu dan telah banyak digunakan peneliti sebelumnya.

Variabel dependen yang digunakan dalam penelitian ini adalah carbon emission disclosure, metode pengukuran yang digunakan yaitu dengan pengamatan mengenai ada atau tidaknya suatu item informasi yang ditentukan dalam laporan tahunan dan sustainability report dengan menggunakan checklist. Variabel ini mengunakan beberapa item yang diadopsi dari penelitian Choi et al : 2013, yang terkonstruksi dari lembar permintaan informasi yang dikembangkan oleh CDP (Carbon Disclosure Project) dengan menentukan lima kategori besar yang relevan dengan perubahan iklim dan emisi karbon yaitu : risiko dan peluang perubahan iklim (CC/Climate Change), emisi gas rumah kaca (GHG/Greenhouse Gas), 
konsumsi energi (EC/Energy Consumption), pengurangan gas rumah kaca dan biaya (RC/Reduction and Cost) serta akuntabilitas emisi karbon (AEC/Accountability of Emission Carbon). Tipe industri dalam penelitian ini diukur dengan menggunakan variabel dummy dimana nilai 1 untuk perusahaan yang termasuk kedalam industri yang intensif dalam menghasilkan emisi (firms in emission intensive industries) yang mencakup energi, transportasi, bahan baku (materials) dan utilitas berdasarkan Global Industry Classification Standard (GICS), sedangkan nilai 0 sebaliknya. Kinerja lingkungan diproksi menggunakan PROPER yang diberikan dalam bentuk peringkat kinerja perusahaan dalam meningkatkan kinerja pengelolaan lingkungannya yang terdiri dari 5 kategori dan masing-masing kategori diwakilkan dengan sebuah warna yaitu emas, hijau, biru merah dan hitam. Pengukuran di dalam penelitian ini menggunakan skala nol sampai lima sesuai dengan jenis warna pada PROPER. Dan profitabilitas diukur menggunakan ROA.

Populasi dari penelitian ini adalah perusahaan non keuangan yang menerbitkan laporan tahunan dan dipublikasikan di Bursa Efek Indonesia (BEI) pada tahun 2015-2017. Pemilihan sampel dilakukan dengan menggunakan metode purposive sampling dengan tujuan untuk mendapatkan sampel yang representatif sesuai dengan kriteria yang ditentukan.

Teknik analisis data yang digunakan dalam penelitian ini dilakukan dengan menggunakan analisis regresi linear berganda dengan melakukan uji statistik deskriptif, uji asumsi klasik, dan uji hipotesis. Penelitian ini menggunakan analisis regresi linear berganda karena mengamati hubungan antara satu variabel terikat (dependen variable) dengan satu atau lebih variabel bebas (independen variable). Adapun persamaan regresi untuk seluruh variabel adalah sebagai berikut:

$\mathrm{CED}=\alpha+\beta 1$ TIPE_INDUS $+\beta 2$ KINERJ_LINGK $+\beta 3$ PROFIT $+e$

\section{HASIL PENELITIAN DAN ANALISIS Analisis Statistik Deskriptif}

Berdasarkan hasil olah data pada Tabel 1, dapat dilihat bahwa variabel dependen yaitu Carbon Emission Disclosure memiliki nilai rata-rata sebesar 0,3483 hal tersebut menunjukkan bahwa rata-rata perusahaan non-keuangan yang terdaftar di Bursa Efek Indonesia masih belum secara keseluruhan mengungkapkan emisi karbon dalam annual report maupun sustainability report.

Tabel 1. Hasil Statistik Deskriptif

\begin{tabular}{|c|c|c|c|c|c|}
\hline \multicolumn{6}{|c|}{ Descriptive Statistics } \\
\hline & $\mathrm{N}$ & Minimum & Maximum & Mean & $\begin{array}{c}\text { Std. } \\
\text { Deviation }\end{array}$ \\
\hline CED & 99 & .11 & .78 & .3483 & .17583 \\
\hline TIPE_INDUS & 99 & .00 & 1.00 & .6667 & .47380 \\
\hline $\begin{array}{l}\text { KINERJ_LIN } \\
\text { GK }\end{array}$ & 99 & 3.00 & 5.00 & 3.2424 & .53626 \\
\hline PROFIT & 99 & -22.14 & 43.17 & 7.3084 & 10.09042 \\
\hline $\begin{array}{l}\text { Valid N } \\
\text { (listwise) }\end{array}$ & 99 & & & & \\
\hline
\end{tabular}

Sedangkan tipe industri memiliki nilai ratarata sebesar 0,6667 yang berarti sebagian besar perusahaan yang dijadikan sampel merupakan industri yang intensif dalam menghasilkan emisi. Sedangkan kinerja lingkungan memiliki nilai rata-rata sebesar 3,2424 pada tahun 2015-2017. Hal tersebut menunjukkan bahwa perusahaan non- 
keuangan yang terdaftar di Bursa Efek Indonesia yang menjadi sampel pada penelitian ini telah melakukan upaya pengelolaan lingkungan sesuai dengan ketentuan perundang-undangan yang berlaku. Pada profitabilitas memiliki nilai rata-rata sebesar 7,3084, hal ini menunjukkan bahwa manajemen di perusahaan non-keuangan yang terdaftar di Bursa Efek Indonesia masih belum efisien dalam mengelola aset.

\section{Uji Asumsi Klasik}

Uji asumsi klasik yang bertujuan untuk melihat untuk melihat apakah data yang digunakan dalam penelitian memiliki distribusi normal dan tidak terjadi masalah multikolonieritas, dan heteroskedastisitas. Uji asumsi klasik yang dilakukan dalam penelitian ini adalah uji normalitas, uji autokorelasi uji multikolinearitas dan uji heterokedastisitas.

Hasil uji normalitas menggunakan uji non-parametik Kolmogrov Smirnov ( $K$ S) menunjukan Assmp Sig (2-Tailed) > 0,05. Hasil uji Kolmogrov-Smirnov menunjukan nilai sebesar 0,077 dengan tingkat signifikansi sebesar $0,162>0,05$ maka dapat disimpulkan bahwa data berdistribusi secara normal. Hasilnya dapat dilihat pada Tabel 2.

Tabel 2. Hasil Uji Normalitas dengan Kolmogrov-Smirnov One-Sample Kolmogorov-Smirnov Test

\begin{tabular}{llr} 
& & \multicolumn{1}{c}{$\begin{array}{c}\text { Unstandardized } \\
\text { Residual }\end{array}$} \\
\hline $\mathrm{N}$ & & 99 \\
\hline Normal Parameters & & .0000000 \\
\hline Most Extreme Differences & Mean & .15689411 \\
\cline { 2 - 3 } & Std. Deviation & .077 \\
\cline { 2 - 3 } & Absolute & .077 \\
\cline { 2 - 3 } & Positive & -.061 \\
\hline Test Statistic & Negative & .077 \\
\hline Asymp. Sig. (2-tailed) & & $.162^{\mathrm{c}}$ \\
\hline Sumber : Data sekunder yang diolah &
\end{tabular}

Hasil uji multikolonieritas, model regresi yang seharusnya tidak ada korelasi antar variabel independen. Kesimpulan dapat diambil berdasarkan nilai tolerance dan nilai variance inflation factor (VIF). Jika nilai tolerance $>0,10$ atau niali $\mathrm{VIF}<10$, maka tidak terjadi multikolonieritas. Berikut ini adalah pengujian multikolonieritas, yaitu sebagai berikut :

Tabel 3. Hasil Uji Multikolinearitas

\begin{tabular}{llll}
\hline \multirow{2}{*}{ Model } & & \multicolumn{2}{l}{ Collinearity Statistics } \\
\cline { 2 - 4 } & & Tolerance & VIF \\
\hline 1 & (Constant) & & \\
\cline { 2 - 4 } & TIPE_INDUS & .927 & 1.078 \\
\cline { 2 - 4 } & KINERJ_LINGK & .909 & 1.101 \\
\cline { 2 - 4 } & PROFIT & .884 & 1.132 \\
\hline
\end{tabular}

Sumber : Data sekunder yang diolah
Hasil uji heteroskedastisitas, uji heteroskedastisitas dalam penelitian ini dilakukan dengan melihat grafik Scatterplot tidak membentuk pola-pola tertentu dan plot menyebar diatas dan dibawah angka 0 pada sumbu Y. Dengan demilikian, dapat disimpulkan bahwa model regresi tidak terjadi heteroskedastisitas.

Berdasarkan hasil uji autokolerasi, menunjukan nilai Durbin-Watson sebesar 1,167 yang berarti memenuhi persyaratan tidak adanya kolerasi antara kesalahan periode $\mathrm{t}$ dan periode sebelumnya, karena $2<$ DW $<+2$ atau $-2<1,167<2$ yang berarti tidak adanya autokolerasi.

Berdasarkan Gambar 1, menunjukan bahwa titik-titik tidak membentuk pola tertentu dan menyebar diatas dan dibawah angka 0 
pada sumbu Y. Dengan demilikian, dapat disimpulkan bahwa model regresi tidak terjadi heteroskedastisitas.

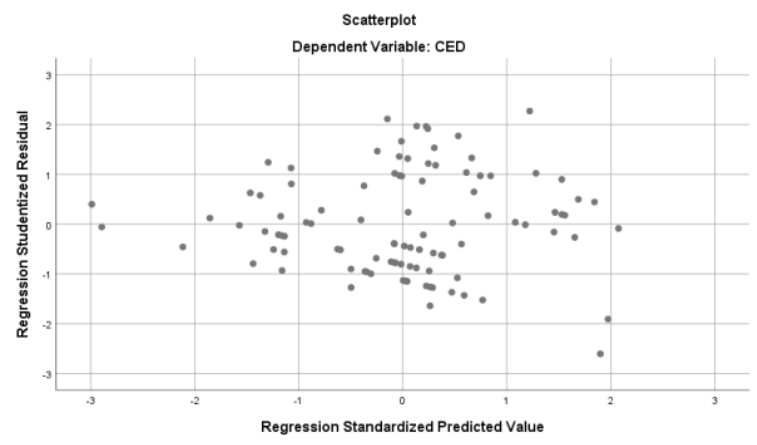

Gambar 1. Grafik Scatterplot

\section{Uji analisis linear berganda}

Analisis regresi merupakan analisis yang digunakan untuk mengukur pengaruh variabel bebas terhadap variabel terikat. Hasil pengelolahan data yang dilakukan dengan bantuan Statistical Product and Service Solution for Windows version 25 yaitu sebagai berikut:

Tabel 4. Hasil Model Regresi Berganda

\begin{tabular}{llll}
\hline & & \multicolumn{2}{c}{$\begin{array}{c}\text { Unstandardized } \\
\text { Modefficients }\end{array}$} \\
\cline { 3 - 4 } & & $\mathrm{B}$ & \multicolumn{1}{c}{ Std. Error } \\
\hline 1 & (Constant) & .061 & .100 \\
\cline { 2 - 4 } & TIPE_INDUS & .113 & .035 \\
\cline { 2 - 4 } & KINERJ_LINGK & .054 & .031 \\
\cline { 2 - 3 } & PROFIT & .005 & .002 \\
\hline
\end{tabular}

Sumber : Data sekunder yang diolah

Persamaan model regresi sebagai berikut: CED $=0,061+0,113$ TIPE_INDUS + 0,054 KINER_LINGK + 0,005 PROFIT

Berdasarkan rumus linear berganda di atas dapat diketahui beberapa hal, yaitu:

a. Dari persamaan regresi tersebut dapat diketahui bahwa variable dependen pada model regresi dalam penelitian ini adalah carbon emission disclosure dengan nilai konstanta sebesar 0,061. Hal ini menunjukkan bahwa jika variabel tipe industri, kinerja lingkungan, dan profitabilitas dianggap konstanta 0, maka rata-rata Carbon
Emission Disclosure nilainya sebesar 0,061 .

b. Nilai koefisien regresi dari tipe industri sebesar 0,113 dengan bertanda positif, hal ini berarti apabila variabel lain tetap, namun variabel Tipe Industri mengalami 1 kenaikan, maka Carbon Emission Disclosure akan mengalami kenaikan sebesar 0,113 .

c. Variabel kinerja lingkungan memiliki koefisien 0,054 dan bertanda positif yang menunjukkan bahwa setiap penambahan tingkat peringkat kinerja lingkungan dalam suatu perusahaan sebesar 1, dengan asumsi variabel lain tetap, maka terjadi peningkatan pengungkapan emisi karbon yang dilakukan sebesar 0,054. Koefisien positif berarti terjadi hubungan positif antara kinerja lingkungan dengan pengungkapan emisi karbon, di mana jika semakin tinggi kinerja lingkungan suatu perusahaan, akan menyebabkan penambahan informasi yang diungkapkan dalam laporan yang dipublikasikan oleh perusahaan

d. Nilai koefisien regresi variabel profitabilitas adalah sebesar 0,005 dengan bertanda positif. Hal ini berarti apabila variabel lain tetap namun profitabilitas mengalami kenaikan sebesar 1, maka Carbon Emission Disclosure akan mengalami kenaikan sebesar 0,005. Artinya, semakin tinggi profitabilitas perusahaan pada tahun sebelumnya, maka membuat tingkat pengungkapan emisi karbon perusahaan pada tahun ini akan meningkat.

\section{Uji Hipotesis}

Uji hipotesis dilakukan dengan analisis regresi linear berganda dengan tingkat signifikansi yang digunakan sebesar $5 \%$. Dalam penelitian ini dilakukan dengan pengujian koefisien determinasi $\left(\mathrm{R}^{2}\right)$ dan pengujian individual atau parsial (uji $\mathrm{t}$ ). Hasil uji koefisien determinasi $\left(\mathrm{R}^{2}\right)$, dapat diketahui bahwa nilai koefesien 
determinasi dari Adjusted $R$ square adalah sebesar 0,179 atau sebesar $17,9 \%$.

Tabel 5. Hasil Uji Koefisien Determinasi $\left(\mathrm{R}^{2}\right)$

\begin{tabular}{lllll}
\hline Model & $R$ & $R$ Square & $\begin{array}{l}\text { Adjusted } \\
\text { Square }\end{array}$ & $R$ \\
\hline 1 & $.451^{\mathrm{a}}$ & .204 & .179 & \\
\hline
\end{tabular}

Sumber : Data sekunder yang diolah

Dari nilai tersebut dapat disimpulkan bahwa 17,9\% variabel Carbon Emission Disclosure dapat dijelaskan oleh variable tipe indnustri, kinerja lingkungan dan profitabilitas. Sedangkan sisanya yakni $82,1 \%$ dijelaskan oleh variabel lain yang bukan termasuk dalam variabel indepeden dalam peneletian ini seperti kepemilikan institusional, pertumbuhan, leverage, ukuran perusahaan dan media exposure.

Jika tingkat signifikansi $<0,05$ maka variabel independen secara parsial berpengaruh signifikan terhadap variabel dependen, dan jika nilai $t_{\text {hitung }}>t_{\text {tabel }}$ maka variabel independen secara parsial berpengaruh signifikan terhadap variabel dependen.

Tabel 6. Hasil Uji Statistik t

\begin{tabular}{|c|c|c|c|}
\hline Model & & $\mathrm{t}$ & Sig. \\
\hline \multirow[t]{4}{*}{1} & (Constant) & .610 & .543 \\
\hline & TIPE INDUS & 3.213 & .002 \\
\hline & $\overline{\text { KINERJ LINGK }}$ & $\mathrm{K} 1.714$ & .090 \\
\hline & $\begin{array}{l}\text { PROFIT } \\
\end{array}$ & 2.974 & .004 \\
\hline
\end{tabular}

Berdasarkan hasil dari Tabel 6, untuk melihat pengaruh antara variabel independen dengan variabel dependen, dengan membandingkan antara $t_{\text {tabel }}$ dengan thitung. $T_{\text {hitung }}$ dapat dilihat pada nilai signifikansi masing-masing variabel. Sedangkan untuk $t_{\text {tabel }}$ dapat diperoleh dengan menggunakan tabel distribusi t dan dengan menggunakan rumus $\mathrm{df}=\mathrm{n}-\mathrm{K}-1$, dimana $\mathrm{n}$ adalah jumlah sampel dan $\mathrm{K}$ adalah jumlah variabel, sehingga ( $\mathrm{df}=99$ 3 - 1 = 95). Dengan menggunakan tabel distribusi t dan taraf signifikansi 0,05 maka diperoleh nilai $t_{\text {tabel }}$ sebesar 1,98525. Jika signifikansi $>0,05 \mathrm{H}_{0}$ diterima dan jika signifikansi < maka $\mathrm{H}_{0}$ ditolak.

\section{Pembahasan Hasil Penelitian}

Pada penelitian ini variabel tipe industri terhadap carbon emission disclosure di perusahaan Non-Keuangan yang terdaftar di Bursa Efek Indonesia tahun 2015-2017 menunjukkan bahwa variabel tipe industri berpengaruh signifikan terhadap carbon emission disclosure. Variabel tipe industri memiliki koefisien positif, yang berarti tipe industri memiliki pengaruh signifikan positif terhadap pengungkapan emisi karbon. Perusahaan yang intensif dalam menghasilkan karbon seperti pertanian, pertambangan, industri dasar \& kimia, dan infrastruktur, utilitas \& transportasi cenderung untuk mengungkapkan informasi yang berkaitan dengan aspek lingkungan dibanding dengan perusahaan yang tidak intensif dalam menghasilkan karbon dari aktivitas operasionalnya. Hal ini karena perusahaan yang intensif mengeluarkan karbon memiliki tanggung jawab yang lebih besar terhadap isu-isu lingkungan. Hal ini sejalan dengan penelitian yang dilakukan oleh Suhardi \& Purwanto (2015), Jannah \& Muid (2014), Cahya (2016), dan Ghomi \& Leung (2013) yang menyatakan bahwa tipe industri berpengaruh signifikan terhadap pengungkapan emisi karbon. Hal ini berarti bahwa pada perusahaan yang tergabung dalam kelompok intensif karbon akan mendapatkan tekanan yang lebih besar oleh masyarakat dan pemerintah daripada perusahaan yang tergabung dalam kelompok non intensif karbon sehingga membuat kelompok intensif karbon lebih peduli dalam melakukan pengungkapan emisi karbon. Namun penelitian ini tidak sejalan dengan penelitian yang dilakukan Pradini \& Kiswara (2013), yang menyatakan bahwa tipe industri tidak berpengaruh signifikan terhadap pengungkapan emisi karbon (carbon emission disclosure). 
Pada penelitian ini variabel kinerja lingkungan terhadap carbon emission disclosure di perusahaan Non-Keuangan yang terdaftar di Bursa Efek Indonesia tahun 2015-2017 menunjukkan bahwa variabel kinerja lingkungan tidak berpengaruh signifikan terhadap carbon emission disclosure. Hal ini berarti bahwa kinerja lingkungan yang diproksi menggunakan PROPER tidak berpengaruh terhadap luas pengungkapan emisi karbon. Dapat dikatakan hal ini bertentangan dengan hipotesis kedua, dimana hipotesis kedua menyebutkan bahwa kinerja lingkungan berpengaruh signifikan terhadap Carbon Emission Disclosure. Perusahaan yang mendapat peringkat PROPER yang tinggi merasa tidak perlu untuk melakukan pengungkapan emisi karbon karena menilai kinerja mereka sudah baik dalam rangka pengurangan emisi karbon. Sedangkan pada perusahaan yang mendapat peringkat rendah cenderung berusaha mendapat kepercayaan masyarakat sehingga secara sukarela mengungkapkan hasil kinerja lingkungannya. Hasil kinerja lingkungan yang tidak berpengaruh terhadap carbon emission disclosure juga dikarenakan dalam pemeringkatan PROPER yang difokuskan adalah permasalahan konservasi sumber daya alam, sistem manajemen lingkungan, dan pelaksanaan CSR (Kementerian Lingkungan Hidup, 2011). Pemeringkatan PROPER tidak menaruh fokus utama dalam permasalahan mengenai pemanasan global ataupun perubahan iklim. Hal ini menyebabkan proper sebagai proksi kinerja kinerja lingkungan tidak berpengaruh terhadap pengungkapan emisi karbon. Hasil penelitian ini selaras dengan hasil penelitian yang dilakukan oleh Majid \& Ghozali (2015) dan Suhardi \& Puwanto (2015) yang menyatakan bahwa kinerja lingkungan tidak mempengaruhi Carbon Emission Disclosure. Penelitian yang dilakukan oleh Dawkins \& Fraas (2011) dan Pradini \& Kiswara (2013) mendapatkan hasil yang berbeda, dimana kinerja lingkungan memiliki hubungan positif dengan pengungkapan lingkungan, yaitu perubahan iklim. Peringkat tinggi yang diberikan oleh PROPER (Program Penilaian Peringkat Kinerja Perusahaan) secara tidak langsung merupakan komitmen perusahaan untuk mengatasi masalah perubahan iklim. Berdasarkan teori stakeholder perusahaan dapat menunjukkan keseriusannya dalam mengatasi masalah lingkungan dengan melakukan pengungkapan emisi karbon yang dapat dijadikan kabar baik bagi para investor.

Pada penelitian ini variabel profitabilitas terhadap carbon emission disclosure di perusahaan Non-Keuangan yang terdaftar di Bursa Efek Indonesia tahun 2015-2017 menunjukkan bahwa variabel profitabilitas berpengaruh signifikan terhadap carbon emission disclosure. Hal ini berarti perusahaan dengan kemampuan yang lebih baik dalam memanfaatkan aset guna mendapat keuntungan secara finansial akan melakukan pengungkapan emisi karbon. Berdasarkan pada kemampuan yang memadai secara finansial, perusahaan yang memiliki profitabilitas yang tinggi lebih leluasa dalam melakukan berbagai jenis pengungkapan yang dilakukan secara sukarela bila dibandingkan dengan perusahaan dengan profitabilitas yang rendah. Selanjutya perusahaan dengan profitabilitas yang tinggi cenderung untuk mengungkapkan kabar baik kepada pasar finansial. Kabar baik ini dapat berupa pengungkapan wajib (mandatory disclosure) maupun pengungkapan sukarela (voluntary disclosure) seperti pengungkapan emisi karbon. Sementara untuk perusahaan dengan profitabilitas rendah memilih untuk lebih fokus pada hal - hal produktif seperti meningkatkan laba perusahaan dan efisiensi dibandingkan membuat pengungkapan sosial lingkungan karena dapat menambah beban operasional perusahaan. Hal ini sejalan dengan penelitian yang dilakukan oleh Suhardi \& Purwanto (2015), Akhiroh \& Kiswanto 
(2016) dan Nurdiawansyah et al (2018) dimana profitabilitas memiliki pengaruh yang signifikan terhadap pengungkapan emisi karbon.

\section{SIMPULAN}

Penelitian ini dilakukan untuk menguji pengaruh tipe industri, kinerja lingkungan, dan profitabilitas terhadap carbon emission disclosure. Penelitian ini menggunakan perusahaan non-keuangan yang terdaftar di Bursa Efek Indonesia (BEI) pada tahun 2015, 2016, dan 2017 secara berturut-turut, dengan total perusahaan yang memenuhi kriteria sampel sebanyak 33 perusahaan.

Setelah melakukan analisis dan pengujian hipotesis mengenai pengaruh tipe industri, kinerja lingkungan, dan profitabilitas terhadap carbon emission disclosure pada 99 sampel yang telah terpilih, dan berdasarkan hasil penelitian yang telah dijelaskan pada bab sebelumnya, maka dapat diambil kesimpulan sebagai berikut :

a. Tipe Industri memiliki pengaruh yang signifikan terhadap carbon emission disclosure dengan tingkat signifikansi untuk tipe industri sebesar 0,002 yang berarti lebih kecil dari taraf signifikansi yaitu 0,05. Dengan demikian, hipotesis yang menyatakan tipe industri berpengaruh signifikan terhadap carbon emission disclosure diterima.

b. Kinerja lingkungan tidak memiliki pengaruh yang signifikan terhadap Carbon Emission Disclosure dengan tingkat signifikansi untuk kinerja lingkungan sebesar 0,095 yang berarti lebih besar dari taraf signifikansi yaitu 0,05 . Dengan demikian, hipotesis yang menyatakan kinerja lingkungan berpengaruh signifikan terhadap carbon emission disclosure ditolak.

c. Profitabilitas memiliki pengaruh yang signifikan terhadap Carbon Emission Disclosure dengan tingkat signifikansi untuk profitabilitas sebesar 0,004 yang berarti lebih kecil dari taraf signifikansi yaitu 0,05. Dengan demikian, hipotesis yang menyatakan profitabilitas berpengaruh signifikan terhadap carbon emission disclosure diterima.

Adapun keterbatasan dalam penelitian ini adalah adanya pengaruh subjektivitas peneliti dalam menilai luas pengungkapan emisi karbon. Hal ini terjadi karena perbedaan sudut pandang dalam menilai pengungkapan tersebut serta tidak adanya ketentuan baku yang dapat dijadikan acuan, sehingga penentuan indeks pengungkapan emisi karbon dapat berbeda untuk setiap peneliti.

\section{DAFTAR PUSTAKA}

1 . , Laporan Hasil Penilaian

Program Peringkat Kinerja

Perusahaan Dalam Pengelolaan

Lingkungan Hidup 2013. Jakarta:

Badan Penerbit Kementerian

Lingkungan Hidup, 2013.

2. No. 71 tahun 2011 mengenai

Penyelenggaraan Inventasrisasi Gas

Rumah Kaca Nasional.

3. Akhiroh dan Kiswanto, The Determinant of Carbon Accounting Disclosures. Jurnal Akuntansi Universitas Negeri Semarang ISSN: 2252-6765, 2016.

4. Barthelot, Sylvie dan Anne-Marie Robert, Climate Change Disclosure : An examination of Canadian Oil and Gas Firms. Vol. 5 pp 106-123, 2011.

5. Borghei-Ghomi, Zahra dan Philomena Leung, An Empirical Analysis of the Determinants of Greenhouse Gas Voluntary Disclosure in Australia. Sciedu Press Vol 2, No1, 2013.

6. Cahya, Bayu Tri, Carbon emission disclosure: Ditinjau Dari Media Exposure, Kinerja Lingkungan, dan Karakteristik Perusahaan Go Publik Berbasis Syariah Di Indonesia, Jurnal Studi Keislaman Vol.5 No.2,2016, ISSN 2541-7061, 2016. 
7. Choi, Bo Bae, Doowon Lee dan Jim Psaros, An analysis of Australian Company Carbon emission disclosures, Pacific Accounting Review, Vol. 25 No. 1, 2013 pp. 58-79, 2013.

8. Clarkson, P. M. et.al., Revisiting the Relation between Environmental Performance and Environmental Disclosure: An Empirical Analysis, Accounting, Organizations, and Society, 33(4-5), 303-327, 2008.

9. Cotter, J. and Najah, M. M., Institutional Investor Influence On Global Climate Change Disclosure Practice, University of Southern Queensland, 2011.

10. Dawkins, C. dan John Fraas, The Impact of Environmental Performance and Visibilityon Corporate Climate Change Disclosure, Journal of Business Ethics, 100(2): 303 - 322, 2011.

11. Jannah, Richatul dan Dul Muid, Analisis Faktor-Faktor yang Mempengaruhi Carbon emission disclosure pada Perusahaan di Indonesia (Studi Empiris pada Perusahaan yang Terdaftar di Bursa Efek Indonesia Periode 2010-2012), Diponegoro Journal Of Accounting, Volume 3, Nomor 2, Halaman 1ISSN(Online):2337-3806, 2014.

12. Kementerian Energi dan Sumber Daya Mineral, Kajian Inventarisasi Emisi Gas Rumah Kaca Sektor Energi, 2013.

13. Kementerian Lingkungan Hidup, Buku 1 Pedoman Penyelenggaraan Inventarisasi Gas Rumah Kaca Nasional. Jakarta: Badan Penerbit Kementerian Lingkungan Hidup, 2012

14. Lorenzo, et al., Factors Influencing the Disclosure of Greenhouse Gas
Emission in Companies World-Wide, Journal of Management Decisions, Vol. 47, pp. 1133-1157, 2009.

15. Majid, R. A. dan Imam Ghozali, Analisis Faktor-faktor yang Mempengaruhi Pengungkapan

Emisi Gas Rumah Kaca pada Perusahaan di Indonesia, Diponegoro Journal of Accounting, 4(4): 1-11, 2015.

16. Nurdiawansyah et al., Carbon Emission Issues in Indonesia, Review of Integrative Business and

Economics Research, Vol 7, Supplementary Issue 3, Departement of Accounting, University of Bandar Lampung, ISSN 2304-1013, 2018.

17. Pradini, H. S. dan Endang Kiswara, The Analysis of Information Content towards Greenhouse Gas

Emissions Disclosure In Indonesia's Companies. Diponegoro Journal of Accounting. 2(2): 1-12, 2013.

18. Perpres No. 61 tahun 2011 mengenai Rencana Aksi Nasional Penurunan Emisi Gas Rumah Kaca.

19. Pratiwi dan Sari, Pengaruh Tipe Industri, Media Exposure dan Profitabilitas terhadap Carbon emission disclosure, Jurnal WRA, Vol 4, No 2, Oktober, 2016

20. Suhardi dan Purwanto, AnalisisFaktor-Faktor yang Mempengaruhi Pengungkapan Emisi Karbon di Indonesi (Studi Pada Perusahaan yang Terdaftar di Bursa Efek Indonesia Periode 2010-2013), Diponegoro Journal Of Accounting, Vol. 4 No.2, 2015.

21. Wang, Jianling, Song Lin, Shujie Yao. The Determinants of Corporate Social Responsibility Disclosure: Evidence From China, The Journal of Applied 
Business Research, Volume 29, Number 6, 2013.

22. Zhang, Shan, Patty McNicholas, and jacqueline Birt, Australian Corporate responses to Climate Change: The Carbon Disclosure Project, Paper to be presented at the RMIT Accounting for Sustainability Conference on the 28th of May 2012, 2012. 